
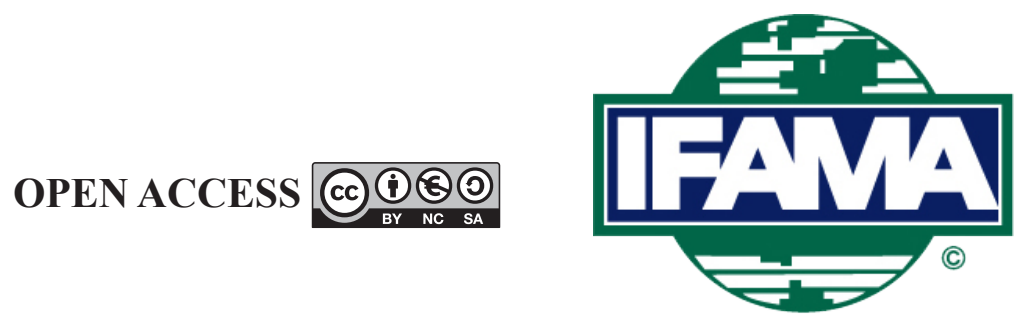

International Food and Agribusiness Management Review

Volume 25, Issue 1, 2022; DOI: 10.22434/IFAMR2021.0058

Received: 11 May 2021 / Accepted: 17 July 2021

\title{
Oatly, a serious 'problem' for the dairy industry? A case study CASE STUDY
}

\author{
Caspar Krampe ${ }^{(\mathfrak{a} a}$ and Adar Fridman ${ }^{\mathrm{b}}$ \\ ${ }^{a}$ Postdoctorial researcher, ${ }^{b}$ Student, Marketing and Consumer Behaviour Group, Wageningen \\ University and Research, Hollandseweg 1, 6706 KN Wageningen, the Netherlands
}

\begin{abstract}
This case study outlines the steps Oatly has taken so far to achieve its goal of becoming the largest 'dairy and milk' producer in the world. Oatly develops, produces and markets dairy and milk analogues, with an overriding ambition to promote structural changes in the dairy industry. Oatly's approach relies on state-ofthe-art technologies that can create dairy analogues and milk-like fluids. The resulting products are marketed under their own brand and promoted by provocative and innovative communication strategies that include storytelling, policy-related activities, social media campaigns and more traditional sales concepts. The company is constantly developing and opening factories that enable them to expand into foreign markets, whilst applying diverse marketing strategies. Following Oatly's example, other retailers and food companies also expressed their interest in dairy and milk replacement products, increasing the market competition.
\end{abstract}

Keywords: Oatly, dairy industry, dairy analogues, technology innovation, marketing, international strategy JEL code: M3, M310, A2, A22

\footnotetext{
${ }^{(i)}$ Corresponding author: caspar.krampe@wur.nl
}

A teaching note has been prepared for this case study. Interested instructors at educational institutions may request the teaching note by contacting the author or IFAMA 


\section{Introduction}

It is 1994, in a sauna in a mountain-house in Sweden, brothers Bjorn and Rickard Öste sit down and exchange notes. Bjorn has just sold his cyber security company and Rickard, a researcher at Lund University, had several patents approved for his oat extraction process, creating an oat-based milk alternative. Bjorn sees immense potential in his older brother's invention, and they decide to co-found Oatly, a decision that will change their lives forever.

Rickard's innovative idea was inspired by the observation that more and more people were reducing their dairy consumption. He identified several reasons for it, such as lactose-intolerance, avoiding milk for personal reasons such as animal welfare and/or to save the environment by reducing emissions that are associated with the milk production. Along with his team of researchers, he tried to process oats into a product that would resemble milk in terms of flavour and nutrition, to address the consumers' rising demand for milk and dairy alternatives.

Although their product has been on the market for nearly thirty years, it wasn't until 2012, when Oatly completely changed the company's image. Today, with having nearly 800 employees, a revenue of $\$ 200$ million and being distributed to more than twenty countries worldwide, Oatly is a game-changer in the food industry.

Yet, Oatly's mission goes beyond producing nutritious dairy analogues, as it will be elaborated in the coming sections. Oatly puts sustainability at the top of its agenda by striving to reduce emissions and rely on nonanimal products. By doing so, Oatly constantly challenges the food industry, aiming to become a leading company that is more transparent and fairer towards consumers, producers and the planet.

\section{Dairy products - a serious problem in the food system?}

Animal-based products play a key role in the factors that contribute to the major challenges of the global food system. The current consumption patterns of the world population pose severe threats in relation to (1) health issues; (2) the environment; (3) food security; and/or (4) animal welfare.

In relation to the human health (1), it is estimated that $68 \%$ of the adult world population suffers from lactose malabsorption, ranging from $4 \%$ in Scandinavian countries up to nearly $100 \%$ in China (Storhaug et al., 2017). Lactose intolerance is a common condition caused by one's reduced ability to digest lactose, due to a decreased production of lactase in the body (Misselwitz et al., 2013). The striking diversity in lactoseintolerance throughout the world is explained by historic dietary patterns. Genetic studies show that the lactase persistence in Europe coevolved with dairy farming, dating back 7,500 years ago (Itan et al., 2009). Besides lactose intolerance, milk allergy remains another serious issue in modern society (Høst, 2002). It is estimated that $3 \%$ of infants suffer from it, which can experience various symptoms upon consumption including the life-threatening anaphylaxis (Høst, 2002). Besides these drawbacks of milk consumption, milk and dairy products are often associated with bone and muscle strength, due to their relatively high content of calcium, potassium as well as vitamin $\mathrm{D}$, which is added via fortification - the process of enriching a food product with additional micronutrients (Calvo et al., 2004; Van Hulzen et al., 2009). Nevertheless, recent studies have also cast doubts over the health benefits of milk. In relation to bone strength, numerous studies found no correlation between milk consumption and reduced risk of fractions due to increased bone strength (Bolland et al., 2015; Feskanich et al., 1997, 2014). Moreover, due to the high saturated fat content of whole milk and various dairy products, regular consumption has been linked to breast cancer in women (Fraser et al., 2020; McCann et al., 2017) and prostate cancer in men (Qin et al., 2007; Song et al., 2013). More and more studies also point towards the health benefits of transitioning to a plant-based diet in general (Fehér et al., 2020; Grant, 2017). Just recently, the EAT-Lancet - a commission consisting of 37 world-leading scientists from 16 countries and various scientific disciplines whose goal is to define targets for healthy diets and sustainable food production - came up with the 'planetary diet', which aims at creating 
dietary paradigms that will allow proper nutrition for the growing world population. The planetary diet is flexitarian and relies very little on animal products (Willett et al., 2019).

Dairy and livestock farming also have an adverse environmental impact (2). Via enteric fermentation, animal agriculture is made responsible for the production of methane, whose effect as a greenhouse gas (GHG) is 28 times higher than carbon dioxide $\left(\mathrm{CO}_{2}\right)$ (Grossi et al., 2019). Animal-based industries are known to be responsible for $12.5 \%$ of the global GHG emissions, while the dairy and beef sectors are responsible for two thirds of them (Rojas-Downing et al., 2017; Westhoek et al., 2011). Models show that halving the amount of meat and dairy products consumed in Europe (and replacing them by plant-based foods on a dietary energybasis), could lead up to $40 \%$ lower nitrogen emissions, $25-40 \%$ lower greenhouse gas emissions; whilst also lowering the current saturated fat intake to the recommended level of less than ten percent (Westhoek et al., 2014). Yet, it is worth noting that the plant-based milk industry also has it downsides. In Thailand, for example, monkeys are abusively trained and forced to climb trees to pick up coconuts, which are later used for coconut milk (PETA, 2019) and coconut is often related to deforestation and biodiversity loss (Meijaard et al., 2020). To produce almonds for almond milk, massive pollination operations are performed in the US, which include shipping vast amounts of bees to California of which many of them die during transport or because of pesticides, pressures and environmental threats (Ferrier et al., 2018). Moreover, almonds require more water than any other crop alternatives (Poore and Nemecek, 2018). Soy and soy-based products have also been under scrutiny as soy is often related to deforestation in the Amazon region. Yet, studies have put this claim in question, saying that most of it is driven by expansion of cattle ranching, and most of the soy is grown as feed for livestock (Barona et al., 2010; Nepsted et al., 2014).

Since World War II, the efficiency of animal production has been the main objective in the previous development of the industry, which nowadays leads to major societal concerns about animal welfare (3). Cows yield more than double the amount of milk in comparison to 50 years ago, which can amount for up to 20,000 kg per lactation (Oltenacu and Broom, 2010). In the majority of dairy farms cows do not graze and are kept indoors (Schuppli et al., 2014), whilst in parallel their calves are separated from the mother cow immediately to guarantee maximal amounts of milk (Ventura et al., 2013). This surge in productivity has also been linked to inferior health, fertility and the life-span of dairy cows, for reasons such as metabolic stress, physical changes due to (in)breeding and minimal or no space for grazing (Oltenacu and Broom, 2010).

The above-mentioned topics are also related to another challenge of the global food system, the food security (4). It is estimated that 2 billion people are currently in a state of food insecurity and this will only rise with the expected world population growth to 9.7 billion by 2050 (FAO, 2020a). In 2017, the yearly average global milk consumption was $98 \mathrm{~kg}$ per capita with a strong correlation between the country's GDP and the amount consumed (FAO, 2017).

Although in Western countries only a minority of consumers eat according to the recommended caloric intake, animal-based consumption is adopted more and more in developing countries because it is associated with prosperity and an improved lifestyle (Azzam, 2021; Kopp, 2019). This is in contrary to the traditional plant-based cuisine in many of those countries. Hence, it is expected that animal-products consumption will continue to rise as these countries develop, along with the effects and consequences of these consumption patterns. Nevertheless, if the goal is to ensure proper nutrition for the world population, as part of the UN Sustainable Development Goals (SDG's), experts advise a major change in the global food system.

\section{Dairy alternatives on the rise}

Although on the global level the consumption of animal products keeps rising, a contrary trend can be observed in Western countries. In those countries, the consumption behaviour involves more plant-based dairy analogous, resulting in three main segments of consumers that drive this consumption patterns. First, people who suffer from milk allergy or lactose intolerance are a small, yet important segment for the dairy alternatives industry. As countries in Asia continue to adopt a more Western lifestyle and diet (and its dairy 
constituents), this segment will grow as these countries show a higher number of lactose intolerance cases in comparison to Western countries. The second group is relatively small and consists of vegan consumers, who do not consume any animal-based products. They are estimated to involve 75 million consumers worldwide (VeganBits, 2020). The third group, which is ever-growing, is the group of vegetarians or flexitarians - those who still consume animal-based products but to a reduced extent. This might be due to a variety of reasons such as health related considerations, environmental related reflections, animal welfare concerns and/or for variety-seeking motives (Bridges, 2018; McCarthy et al., 2017).

The global dairy alternatives market is estimated to be valued at $\$ 22.6$ billion in 2020 , and according to projections, it will reach $\$ 40.6$ billion by 2026 (Markets and Markets, 2020), a staggering rise by all means.

Despite the growing demand, there are several setbacks that restrain the market from expanding even faster. As mentioned before, some people across the globe suffer from allergies associated with plant-based sources, especially soy and almonds. It is estimated that $0.4 \%$ of children are allergic to soy - though half of them outgrow it around the age of seven (Savage et al., 2010). Tree-nut allergies (the majority of which are derived from nine nuts: walnut, almond, pistachio, cashew, pecan, hazelnut, macadamia, Brazil nut and pine nut) are estimated to be prevalent in 1\% of the world population (Mandalari and Mackie, 2018; Weinberger and Sicherer, 2018). While almond and cashew allergies are relatively rare, these components are commonly used for producing dairy alternatives; and this prevents companies from reaching certain audiences. Oat-allergies are, however, rare, yet there is still insufficient research with regard to their prevalence, and further research efforts are needed. Another challenge that the dairy-alternatives industry faces is the volatile prices of raw materials, which are relatively cheap, but the prices often fluctuate. As a well-established industry and being less affected by climate issues, dairy prices are lower than most of its substitutes and alternatives (FAO, 2020b).

Cultural aspects might be another challenge for the dairy alternatives industry. Despite dairy-alternatives becoming more mainstream, preferences for milk are deeply rooted in Western cultures, notably in Northern Europe and the US. Milk consumption, especially for older generations, is associated with childhood memories and tradition. In Europe, for example, one can think of the classical image of cows grazing in the alps, an idyll that is often used by the dairy industry for marketing purposes (Haas et al., 2019). In addition, alternative milk producers face the challenge of dealing with current legislation and policies that are believed to favour milk producers due to good lobbying. An aspect that is particularly found in the European Union and that will be further discussed in the next section.

\section{The birth of Oatly}

Shortly after the Öste brothers' 'sauna-conversation' about starting an oat-drink company, they raised the initial capital and set up the team to launch Oatly. Retrospectively, this was the perfect timing as around the same time the United States Food and Drugs Administration (USFDA) approved the use of health claims on products containing a certain amount of oats, thanks to their cholesterol-reducing abilities (USFDA, 2020). This further contributed to the positive public perceptions of oats, setting the stage for the company's launch. The company's initial strategy was to sell their products as slimming products in order to make their initial mark in the industry. Only later on they marketed them as lactose-free milk alternatives (Ledin and Machin, 2020).

But also the transition from the tech-industry to the food industry was perceived as a challenge. In interviews, Bjorn Öste explains how strange the transition was:

I was at my first food expo, and you see people come in and drink your product. I came from the software industry; I was used to being able to reassure clients by saying that we will fix the issues they experienced with our software in the next update. When you meet consumers in the food industry, they either like it or not, and you can see it straight away on their face. This intrigued me. ${ }^{1}$

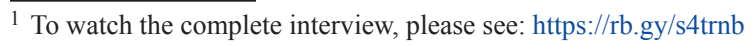


After being on the top the Oatly management for some time, both brothers decided to step down from actively managing the company but remained members of the board and the main shareholders. Rickard is working in various projects and is developing new food products in a research company called Aventure AB. He also works part-time as a professor at the Department of Applied Nutrition at Lund University in Sweden. Bjorn has founded another company, Good Idea Drinks, which produces drinks that regulate blood sugar levels after meals.

\section{From oat to milk - how it is made?}

Oat is a minor cereal crop, based on annual production. Although it is primarily used as animal feed, it has been gaining popularity especially in breakfast products because of its nutritional profile and health benefits (Deswal et al., 2014). Oats contain the soluble fibers $(1 \rightarrow 3),(1 \rightarrow 4)-\beta$-D-glucan, which are associated with substantial health benefits, such as reducing risk for cardiovascular diseases by lowering the cholesterol and glucose levels (Ruxton and Derbyshire, 2008). Moreover, oats are a good source for protein and fats. Whilst $\beta$-glucans can serve as fat replacer or stabilizer (Deswal et al., 2014). In 2017, a life cycle assessment (LCA) was commissioned for Oatly's annual sustainability report. This LCA study found that in Sweden, the production of oat milk accounts for $80 \%$ less GHG emissions, $80 \%$ less land and $60 \%$ less energy-use in compare to cow milk (Oatly, 2017).

As stated above, the technological advancement was done through the work of a research team at Lund University, led by Rickard Öste. To produce oat milk, several steps are needed. First, the oats must be milled and mixed with water. Then, specific enzymes are added in large tanks, breaking down oat starch. The starch is partially broken down into maltose, which is the sugar responsible for the sweetness of the final product. Afterwards, a separation process takes place, in which the bran (the oat's shell) is removed and the 'oat base' remains. This includes the fibers ( $\beta$-glucans amongst) and all macronutrients. Then ingredients are added and mixed, namely with rapeseed oil, calcium, salt and vitamins. Rapeseed oil is of special importance, because it serves as an emulsifier, keeping the oat components and the water blended together, contributing to the product's signatory smooth and creamy texture. Later, an ultra-high temperature process is applied to ensure shelf stability at ambient temperature; before the product is homogenized so that the fat droplets are small and the liquid is stable. The last step is the packaging and distribution. According to Oatly, they can produce between 7,500-8,000 packages per hour (Oatly, 2020). The company's initial goal was to solely use organic oats in their products, yet according to European/worldwide regulations, a product cannot be labelled as organic, if calcium and vitamins are added to it during processing (EC, 2007; USFDA, 2021). But to serve as a proper substitute, Oatly's oat drink must be comparable to cow milk nutrition-wise, therefore the decision to keep the added nutrients was made over being certified organic. Nonetheless, the company also offers an organic version of their flagship oat milk, which lacks the aforementioned components.

While Oatly's wide and diverse offer of oat-based products (since its foundation in the 90's, Oatly has extended its line of products significantly, now offering nearly 50 different oat-based products, including various milk substitutes, yoghurts, whipped cream, spreads, ice cream and more) and the fact that oat milk is gaining popularity all around the world, oats are cheap and the extraction technology is not very complex. Therefore, Oatly's advantage lies in how it uses their technology to develop new products and how it markets them.

\section{Creating, communicating, pricing and delivering a 'milk' experience}

\subsection{Rebranding and key people behind the 'modern' Oatly}

It is October 2019, Americans all across the United States are doing their weekly grocery shopping. As they enter their favourite grocery store, multiple signs hanging on the front door, stating that the grocery store completely ran out of some Swedish oat drink and that it is still not yet clear when they can restock, can be observed. At home, they open the newspaper and read the headline: 'Dairy alternative company to open 19,000 square feet production plant worth $\$ 15$ million in New Jersey, to try and meet increasing demand'. 
Seven years earlier, John Schoolcraft, an experienced creative director, receives a phone call from Toni Peterson, a former colleague, who tells him that he was recently appointed as chief executive officer (CEO) at 'this' oat milk company and that he wants him onboard. Looking at the product design at the time, John was horrified, saying that he will join him only if he is allowed 'to kill the marketing department'. 2

John was obviously referring to a different approach on how the company should be run. He decided to put the people in charge that are responsible for being creative and work at the heart of the food company, being present in all meetings of all departments - from product development to sales. This, as John Schoolcraft puts it, builds collaboration and trust within the company, since there is no more need for briefing meetings that may cause misunderstandings. Knowing Schoolcraft's unique talent, Toni Peterson was pleased to welcome John and appointed him immediately. This was the birth of the 'Oatly Department of Mind Control' as he likes to call it. Upon his arrival, John described the company's behaviour similar to 'a Dutch multinational, just indistinguishable from anything else on the shelves' (Figure 1). ${ }^{3}$

\subsection{Communication}

Oatly's communication style in commercials and advertisements is bold, opinionated and often calling out its dairy-based competitors.

The first large advertising campaign initiated by Oatly's new creative department carried the slogan: 'It's like milk but made for humans'. After the launch, the Swedish milk lobby filed a 174-page lawsuit on Oatly. Among others, for the following illustration (Figure 2), saying it is misleading people about which body-part cow milk is derived from. As soon as the company received the lawsuit, they decided to upload it entirely on their website. Then, they printed full-page ads in Sweden's major morning newspapers, saying that the milk lobby is feeling threatened and that this is the reason why they are suing them. Oatly then took it to the next level, with the company's CEO Toni Peterson sitting in an oat field, playing the piano and repeatedly singing the Oatly slogan (this later on became the company's Superbowl commercial). ${ }^{4}$

In one of his talks, John Schoolcraft says that they enjoyed this campaign so much, that they 'literally put this ad everywhere'. This created enormous traffic over social media and television, and it is often considered as the turning point for the company, improving their yearly revenues from $\$ 20$ million to $\$ 200$ million in a matter of a few years.

\footnotetext{
${ }^{2}$ Available at: bit.ly/3w9IWMs

${ }^{3}$ Available at: bit.ly/3u5f4Pu

${ }^{4}$ Available at: bit.ly/3m5lv2e
}

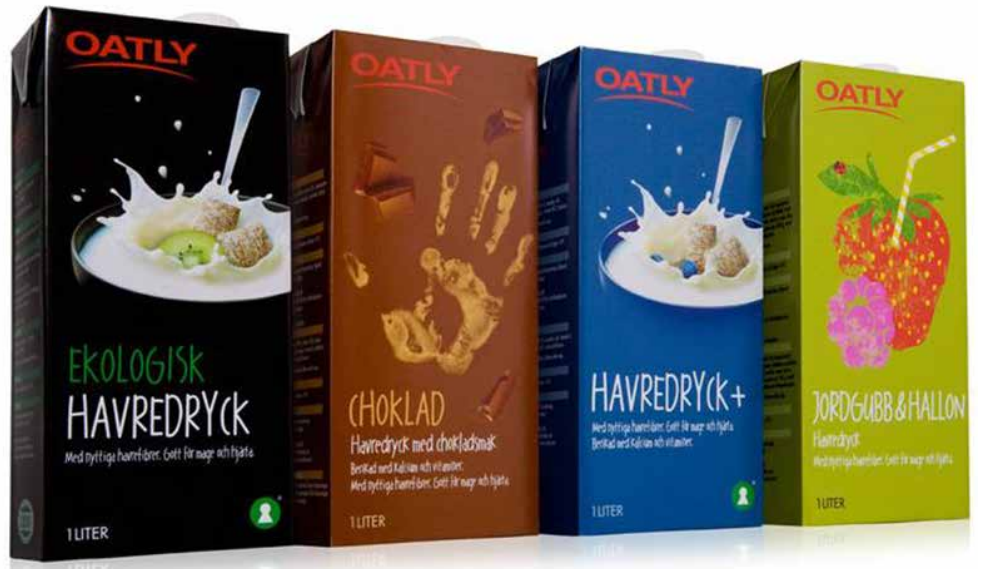

Figure 1. Oatly's initial package design. 


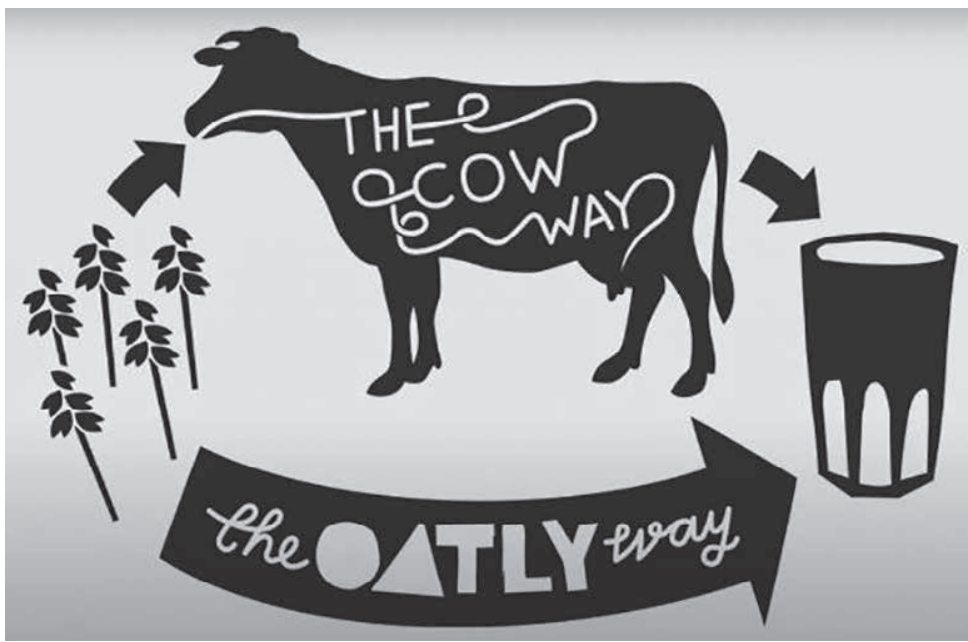

Figure 2. An Oatly illustration.

Seeing how well this campaign worked, it became Oatly's mission to try and make the company's messages personal, opinionated, provocative and witty, to make their products relatable rather than create an image of a food corporation, similarly to most products consumers might see in grocery stores. Although the company has expanded its distribution to a wide range of markets around the world, Oatly puts large efforts in remaining true to its vision and goals and to retain its integrity and legitimacy.

Later on, Arla, the largest dairy producer in Scandinavia, came up with a series of commercials that targeted Oatly, making fun of plant-based alternatives. In the commercials, they showed people using a dairyalternative and called it 'Pjölk' or 'Brölk', names that sound like the Swedish word for milk (mjölk), yet it is not the 'real thing'. The slogan of their campaign was that 'only milk tastes like milk'. In reaction to this commercial, Oatly responded with temporarily printing all of their milk products with the names 'Pjölk' and 'Brölk' printed largely on their packages (Figure 3).

Oatly also used unusual approaches, doing things 'that a marketing department would never do'. For example, they noticed that the inside part of the crème fraiche substitute packaging was empty and thought of a funny way to engage people after they consumed the product. They used this space as a platform to look for a romantic partner for one of the company's workers or used this to advertise a number of things

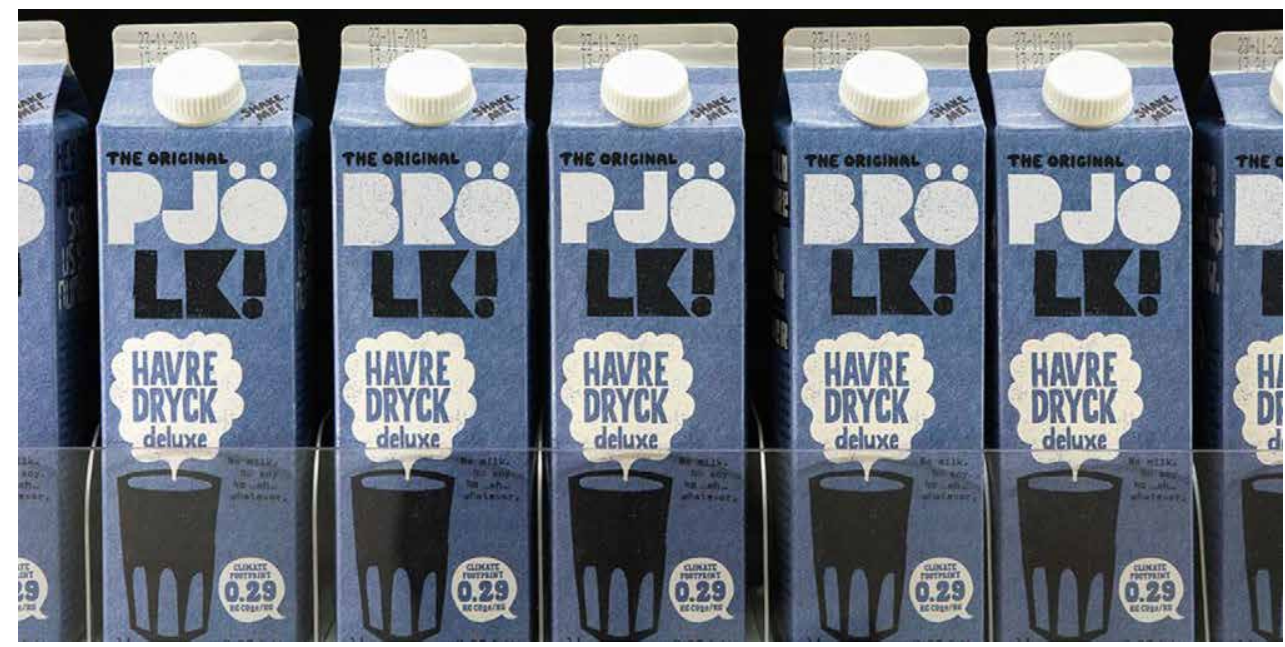

Figure 3. Oatly's temporary packaging, printing the names 'Pjölk' and 'Brölk' in reaction to Arla's campaign. 
the company was giving away, for example a bicycle, $10 \mathrm{~kg}$ barbells, a pair of ice skates and 342 issues of National Geographic from the early 1990's, with personal emails printed on the ad for those who are interested.

A more recent campaign by Oatly is called 'Hey food industry, show us your numbers'. After six months of work and research, Oatly became the first ever company to display a carbon label on their products, stating their relative carbon footprint.

Oatly also responded to current challenges with its creative ideas. On the $23^{\text {rd }}$ of October 2020, the EU Parliament voted yes on Amendment 171 (AM171), which, if approved, would have had the following consequences for the industry of dairy alternatives:

- 'Does not contain milk' could not be used on packaging;

- 'Alternative to...' could not be used on packaging;

- Climate impact comparisons could not be made between plant-based and dairy products;

- The word 'creamy' cannot be used for any dairy alternatives;

- Plant-based products might not be allowed to have the same packaging shape as dairy products.

In reply to this decision, Oatly launched its most recent campaign - 'Are you stupid?'. This includes a series of YouTube videos demonstrating that consumers are very capable of distinguishing milk from its alternatives. ${ }^{5}$ Additionally, an online quiz is available on their website for consumers to test whether 'they are stupid' ${ }^{6}$

These are all interesting examples on how to engage consumers, yet the company also started a petition calling to reject Amendment 171, which surpassed 450,000 European citizen signatures and in May 2021, the European Parliament decided to withdraw Amendment 171 by a vote of 124-37.

Besides the indicated marketing campaigns, Oatly also runs a monthly program named 'Je Ne Sais Quoi of the Month', in which they provide a $\$ 1000$ grant for green and socially responsible initiatives from all over the world and promotes them on their website and social media platforms. From an initiative of developing a recycling system for organic menstrual products to a group of climate-active Finnish grandmothers, Oatly uses its increasing publicity power to make a positive impact in other domains. Constantly challenging the norm, the brand is at the forefront of driving the food industry into becoming more transparent.

\subsection{Pricing}

In many countries cow milk is considered a staple product and the dairy industry in the EU is well-established. Moreover, the EU provides subsidies for dairy farms, which eventually results in lower prices for consumers (Latruffe et al., 2017). The advantage of plant-based alternatives is that their ingredients are cheaper and require less time and energy (Grant and Hicks, 2018). Companies of plant-based alternatives can therefore compete with the milk prices. Although in 2021 the retail prices of Oatly are slightly higher than the prices for cow milk, the gap is shrinking by the day and as the dairy alternatives market will grow, the prices are expected to eventually match.

\subsection{Distribution}

In 2016, after establishing itself in Europe, especially in Scandinavia and the UK (Oatly, 2017), Oatly entered the United States market and decided to take an unusual approach. Instead of investing substantial amounts of money in social media campaigns, using Facebook or Instagram, Oatly researched and identified coffee shops across the country that could serve as informal brand ambassadors for its product. The company identified ten high-end coffee shops in major American cities, which were favoured by locals and served top-quality coffee. Company representatives offered these coffee shops free samples, successfully pitching

\footnotetext{
${ }^{5}$ Available at: bit.ly/3sA1W11

${ }^{6}$ To play the quiz, please visit: https://www.oatly.com/uk/stop-plant-based-censorship/test
} 
their product so that they embraced Oatly's drink. By the end of Oatly's first year in America, its oat milk was present in over 1000 coffee shops. This word-of-mouth approach worked and branded Oatly's drink as the perfect milk alternative to add to one's coffee. Followed by this success, it was only a matter of time until Oatly was distributed in major retailers such as Whole Foods or Target. In 2019 Oatly was available in more than 7,000 stores in the US and on March, the $1^{\text {st }} 2021$, Starbucks - one of the largest coffee chain in the world - announced its partnership with Oatly.

\section{Dairy alternatives in the perspective of the global food industry}

Besides Oatly, there are numerous companies that produce and market dairy alternatives, with varying ingredients such as soy, almonds and coconut. The growing market has prompted an increasing number of actors to get involved, whether by starting new companies or investing in existing ones. A prominent example is Alpro, which was founded in Belgium in 1980 and produces mostly soy-based dairy alternatives. Alpro was bought in 2009 by Dean Foods, the largest dairy subsidiary in the United States, for $\$ 455$ million. $^{7}$ Consecutively, WhiteWave Foods, the daughter company of Dean Foods that marketed Alpro, took off as an independent company, with Dean Foods selling their remaining shares in 2013. In July 2016 it was announced that WhiteWave Foods is purchased by Danone, one of the largest food companies in the world, for $\$ 10.4$ billion. ${ }^{8}$ Besides the large sums of money involved, this acquisition symbolises the growing trend of plant-based dairy alternatives, and perhaps even, as passing the torch and acknowledging the shift from traditional milk to plant-based products. Another example is the Canadian company Daiya which produces dairy alternatives such as cheese, yoghurt and cream, which has been acquired by Otsuka Pharmaceutical, a large Japanese pharmaceutical company, for \$326 million in July $2017 .{ }^{9}$

The rise in demand is also being met by grocery store chains, which are now creating entire product lines of their own private-label plant-based dairy alternatives. In general, grocery stores do not have the capacity of creating compelling branding and investing in high-quality technologies for each product, thus using the option of private-labels allows for entering markets of varying products categories. Private-label products are designed to be cheaper than its competitors, targeting a wide range of market segments. In the US for example, private-label products accounted for $\$ 143$ billion in sales in 2019, with 3.7\% year-on-year growth (GFI, 2020). In its report from 2020, The Good Food Institute found that in the more developed plant-based products such as meat, milk and ice cream, if 'private-label' was considered a brand, it would rank among the top 10 plant-based companies in terms of sales (GFI, 2020).

Most Dutch supermarkets now offer a selection of soy, almond and oat drinks as part of their private-label strategy, and the private-label market share in the Netherlands is estimated to be as high as $27 \%$ (Nielsen, 2018).

Another promising technology that needs to be considered is cultured dairy products. Most companies nowadays use technologies that produce dairy proteins such as casein and whey, by fermentation of certain microorganisms and the use of bioreactors. These products are considered vegan since animals are not part of the process, yet the proteins are similar to those produced by cows. An example is the US company Perfect Day, which produces dairy protein ingredients for the industry. These ingredients are now used in vegan ice creams by Graeter's. In late 2019 the company raised $\$ 140$ million, which later expanded to $\$ 300$ million in July $2020 .{ }^{10}$

Oatly's success also attracted a number of large investors, mostly venture capital funds. In September 2020, Oatly's environment-oriented consumer base was enraged, when it sold a stake of the company to Blackstone Group for \$200 million, valuing the company at \$2 billion. Blackstone is a private-equity giant that includes

\footnotetext{
${ }^{7}$ More info at: https://www.deanfoods.com/newsroom/news/dean-foods-completes-acquisition-of-alpro/

${ }^{8}$ More info at: https://tinyurl.com/ysdy3sxt

${ }^{9}$ More info at: https://www.otsuka.co.jp/en/company/newsreleases/2017/20170727_1.html

${ }^{10}$ More info at: https://fortune.com/2020/07/08/perfect-day-300-million-series-c/
} 
Oprah Winfrey, Natalie Portman and the entertainment company founded by Jay-Z. Blackstone has previously been linked to various operations in the Amazon rainforest related to deforestation, an accusation that they have strongly denied. Moreover, Blackstone's CEO, Stephen Schwarzman, has donated large amounts for Donald Trump's re-election campaign, a person whose views on climate change and the environment are opposite to Oatly's mission and agenda (Jotzo et al., 2018). In response to the ongoing discussion on Twitter, Oatly released a statement explaining its view on the deal, saying that this investment would have otherwise gone towards unsustainable ventures, allowing them to expand their mission of increasing plant-based diets around the world, and reducing GHG emissions.

On February $23^{\text {rd }} 2021$, Oatly officials announced that they submitted a confidential filing for an initial public offering (IPO), valuing the company at $\$ 10$ billion, and since the $20^{\text {th }}$ of May, 2021, the company had its IPO and is now traded on the Nasdaq stock exchange market.

\section{Oatly's upscaling strategy}

With the expected incoming capital due to investments and its IPO, Oatly is set to upscale and dramatically increase its size and production capacities in the years to come. As companies grow and more money is involved, maintaining integrity becomes more difficult. Will Oatly remain true to its vision and ideals? Will it manage to reach certain segments that are unfamiliar with milk alternatives? And what about emerging markets?

\subsection{Production}

In most of its years of existence, Oatly outsourced its production to sub-suppliers, with the main one being the Swedish dairy company Skånemejerier, until in the early 2010's the increasing demand became nearly impossible to meet. Then, a development centre and factory were built in Landskrona, Sweden, from which all of its products were manufactured. In 2019, the company opened two new factories - one in Vlissingen, the Netherlands, designed to produce 120 million litres of oat milk per year, and another in Millville, New Jersey capable of producing nearly 3 million litres of oat base (the main ingredient in Oatly's products). ${ }^{11} \mathrm{In}$ 2020 the company opened its second US factory in Ogden, Utah, and in March 2021, the company announced that it will build its largest factory to date, in the United Kingdom. With a production capacity of about 450 million litres per year, this factory will open at the beginning of 2023 and is set to become the company's most advanced property, with a goal of using $100 \%$ renewable energy by $2029 .{ }^{12}$ With its set of factories in Europe and in the US, Oatly is rapidly expanding its production capacities, which will allow it to continue its growth around the globe and reduce costs for consumers.

Moreover, Oatly is looking into solutions to reduce its carbon footprint on transport. In May 2020, it was announced that the company will join forces with Einride, a Swedish transport company that specializes in electric vehicles. ${ }^{13}$ As part of this collaboration, Oatly announced a future transition in its product transportation to an all-electric fleet of trucks produced by Einride. This could lead to a reduction of up to $87 \%$ of the company's transportation carbon footprint. Although initially this transition only concerns Oatly's operations in Sweden, their plan is to upscale it and to have all its fleets entirely electric.

\subsection{Internationalisation}

Oatly is now available in more than 20 countries across Europe, Asia and North America. Having started in Sweden, and gradually spreading around Europe and to the United States, Oatly is constantly searching for new markets. With the recent financial boost it received, it is very likely that their products will become available in more remote parts of the globe.

\footnotetext{
${ }_{11}$ More info at: https://bloom.bg/31XvJbp

12 More info at: https://bbc.in/3mFOXMw

${ }^{13}$ More info at: https://bit.ly/39Xwztg
} 
Though their messages need to be translated (Oatly's website is available in many languages), it appears that the core of their mission is kept when launching their products in different countries. In early 2018, Oatly started its operations in China, by forming a joint venture with China Resources Corporation (CRC) - a significant Chinese conglomerate. Coffee drinking is becoming more and more popular in China (Statista, 2021), and the big cities now have thousands of boutique coffee shops. First in Shanghai, Oatly took the same approach as they did in the major cities in the US - win over the high-end coffee shops baristas. Moreover, an important advantage that came through the joint venture with CRC is that the corporation owns Pacific Coffee, one of the largest coffee chains in China, and Ole, a chain of premium grocery stores. Upon its launch in China, Oatly was available in both, allowing for the local audience to get acquainted with their product. Moreover, cross collaborations between two brands have become popular in China in recent years and Oatly has found a unique collaboration with HEYTEA, a highly appreciated milk-tea brand with 268 stores in China and Singapore. In addition, Oatly is present on various social media platforms and, as for China, local platforms such as WeChat and Weibo, which are widely used. Although the company had presence on Chinese e-commerce platforms, most of its marketing was done via local coffee shops. When the COVID-19 pandemic hit the world economy, Oatly's aspirations in China were at serious risk, mostly due to the lockdown as caused by the pandemic. In the aforementioned interview with Frontier, co-founder Bjorn Öste mentions that the company's board 'were panicking', and that they thought they had lost their footstep in the Chinese market altogether. Yet, thanks to the Oatly's strong consumer base and brand loyalty, people who were confined were still seeking oat-milk to add to their tea or coffee at home, and through their presence on e-commerce platforms they managed to meet the demand, even beyond coffee shops. As Oatly will expand and launch in more countries, one can expect that their strategy will remain rather similar - create a great coffee (or tea) experience for people with their oat milk, and create brand loyalty based on the quality of their product.

\subsection{Appealing to different market segments}

The market for Oatly's products consists of various different segments. In its first years, Oatly's two main market segments were lactose-intolerant people and vegans. Those two segments did not require special strategies, as they were naturally seeking dairy alternatives. Oatly's main focus was to create a product that would compete with milk nutrition-wise, and will be of high quality, thus trying to transform one-time customers into loyal customers. Nowadays, as the vegan and vegetarian trends are evolving and an increasing number of people adopt a flexitarian diet - especially in the younger generation (Sprouts Farmers Market, 2021) - more market segments are unfolding. Moreover, coffee drinking is on the rise, especially amongst millennials and the Generation-Z. In the US, specialty coffee sales increase in up to $20 \%$ per year, whilst artisanal coffee shops are favoured by younger generations (NCA, 2020). The coffee-drinking segment is crucial for Oatly as it has been the key to its success in the United States and China.

Next, consumers may have varying perceptions and motivations within segments. To date, oats are considered the most sustainable dairy alternative when emissions, land and water use are taken into account (Poore and Nemecek, 2018). Yet, novel ingredients may prove to be more sustainable, shifting environment-conscious consumers towards them. In terms of health-conscious consumers, Oatly tries to diversify its array of products to answer as many consumer needs as possible. From oat drinks with varying fat contents (whole, semi, skinny) and organic options, up to explaining in detail 'what's amazing' and 'what might be less amazing' about each product on its website, Oatly is trying to address consumers' health expectations.

Finally, there are the price-sensitive dairy alternatives seekers - students for example. As Oatly's production capacities grow and more factories around the world open up, prices for consumers will be decreased to meet those of cow milk. This will allow people who normally would purchase milk to purchase plant-based options for financial reasons. Nevertheless, private labels will still be cheaper than Oatly, since the Swedish company wants to maintain its branding and does not want its products to be perceived as cheap or low in quality. 


\section{References}

Azzam, A. 2021. Is the world converging to a 'Western diet'? Public Health Nutrition 24(2): 309-317. https:// doi.org/10.1017/S136898002000350X

Barona, E., N. Ramankutty, G. Hyman and O.T. Coomes. 2010. The role of pasture and soybean in deforestation of the Brazilian Amazon. Environmental Research Letters 5(2): 024002. https://doi.org/10.1088/17489326/5/2/024002

Bolland, M.J., W. Leung, V. Tai, S. Bastin, G.D. Gamble, A. Grey and I.R. Reid. 2015. Calcium intake and risk of fracture: systematic review. BMJ 351: h4580. https://doi.org/10.1136/bmj.h4580

Bridges, M. 2018. Moo-ove over, cow's milk: the rise of plant-based dairy alternatives. Practical Gastroenterology 21: 20-27.

Calvo, M.S., S.J. Whiting and C.N. Barton. 2004. Vitamin D fortification in the United States and Canada: current status and data needs. The American Journal of Clinical Nutrition 80(6): 1710S-1716S. https://doi.org/10.1093/ajen/80.6.1710S

Deswal, A., N.S. Deora and H.N. Mishra. 2014. Optimization of enzymatic production process of oat milk using response surface methodology. Food and Bioprocess Technology 7(2): 610-618. https://doi. org/10.1007/s11947-013-1144-2

European Commission (EC). 2007. Council Regulation (EC) No 834/2007 of 28 June 2007 on organic production and labelling of organic products and repealing Regulation (EEC) No 2092/91. Official Journal of the European Union L 189: 1-23. Available at: http://data.europa.eu/eli/reg/2007/834/oj

Fehér, A., M. Gazdecki, M. Véha, M. Szakály and Z. Szakály. 2020. A comprehensive review of the benefits of and the barriers to the switch to a plant-based diet. Sustainability 12(10): 4136. https://doi. org/10.3390/su12104136

Ferrier, P., R.R. Rucker, W.N. Thurman and M. Burgett. 2018. Economic effects and responses to changes in honey bee health. Economic Research Report No. 246. Economic Research Service, U.S. Department of Agriculture, Washington, DC, USA.

Feskanich, D., W.C. Willett, M.J. Stampfer and G.A. Colditz. 1997. Milk, dietary calcium, and bone fractures in women: a 12-year prospective study. American Journal of Public Health 87(6): 992-997.

Feskanich, D., H.A. Bischoff-Ferrari, A.L. Frazier and W.C. Willett. 2014. Milk consumption during teenage years and risk of hip fractures in older adults. JAMA Pediatrics 168(1): 54-60. https://doi:10.1001/ jamapediatrics.2013.3821

Food and Agriculture Organization (FAO). 2017. FAOSTAT. Per capita milk consumption. FAO, Rome, Italy.

Food and Agricultural Organization (FAO). 2020a. The state of food security and nutrition in the world (SOFI). FAO, Rome, Italy. Available at: http://www.fao.org/documents/card/en/c/ca9692en/

Food and Agriculture Organization (FAO). 2020b. FAOSTAT. Producer prices - milk, oats. FAO, Rome, Italy.

Fraser, G.E., K. Jaceldo-Siegl, M. Orlich, A. Mashchak, R. Sirirat and S. Knutsen. 2020. Dairy, soy, and risk of breast cancer: those confounded milks. International Journal of Epidemiology 49(5): 1526-1537. https://doi.org/10.1093/ije/dyaa007

Grant, C.A. and A.L. Hicks. 2018. Comparative life cycle assessment of milk and plant-based alternatives. Environmental Engineering Science 35(11): 1235-1247. https://doi.org/10.1089/ees.2018.0233

Grant, J.D. 2017. Time for change: benefits of a plant-based diet. Canadian Family Physician 63(10): 744.

Grossi, G., P. Goglio, A. Vitali and A.G. Williams. 2019. Livestock and climate change: impact of livestock on climate and mitigation strategies. Animal Frontiers 9(1): 69-76. https://doi.org/10.1093/af/vfy034

Haas, R., A. Schnepps, A. Pichler and O. Meixner. 2019. Cow milk versus plant-based milk substitutes: a comparison of product image and motivational structure of consumption. Sustainability 11(18): 5046. https://doi.org/10.3390/su11185046

Høst, A. 2002. Frequency of cow's milk allergy in childhood. Annals of Allergy, Asthma \& Immunology 89(6): 33-37. https://doi.org/10.1016/S1081-1206(10)62120-5

Itan, Y., A. Powell, M.A. Beaumont, J. Burger and M.G. Thomas. 2009. The origins of lactase persistence in Europe. PLoS Computational Biology 5(8): e1000491. https://doi.org/10.1371/journal.pcbi.1000491

Jotzo, F., J. Depledge and H. Winkler. 2018. US and international climate policy under President Trump. Climate Policy 18(7): 813-817. https://doi.org/10.1080/14693062.2018.1490051 
Kopp, W. 2019. How western diet and lifestyle drive the pandemic of obesity and civilization diseases. Diabetes, Metabolic Syndrome and Obesity: Targets and Therapy 12: 2221. https://doi.org/10.2147/ DMSO.S216791

Latruffe, L., B.E. Bravo-Ureta, A. Carpentier, Y. Desjeux and V.H. Moreira. 2017. Subsidies and technical efficiency in agriculture: evidence from European dairy farms. American Journal of Agricultural Economics 99(3): 783-799.

Ledin, P. and D. Machin. 2020. Replacing actual political activism with ethical shopping: the case of Oatly. Discourse, Context \& Media 34: 100344. https://doi.org/10.1016/j.dcm.2019.100344

Mandalari, G. and A.R. Mackie. 2018. Almond allergy: an overview on prevalence, thresholds, regulations and allergen detection. Nutrients 10(11): 1706. https://doi.org/10.3390/nu10111706

Markets and Markets. 2020. Dairy alternatives market by source (soy, almond, coconut, oats, rice, hemp), application (milk, yogurt, ice creams, cheese, creamers), distribution channel (supermarkets, health food stores, pharmacies), formulation, and region - global forecast to 2026. Markets and Markets, Northbrook, IL, USA. Available at: https://www.marketsandmarkets.com/Market-Reports/dairyalternative-plant-milk-beverages-market-677.html

McCann, S.E., J. Hays, C.W. Baumgart, E.H. Weiss, S. Yao and C.B. Ambrosone. 2017. Usual consumption of specific dairy foods is associated with breast cancer in the Roswell Park Cancer Institute Data Bank and Biorepository. Current Developments in Nutrition 1(3): e000422. https://doi.org/10.3945/ cdn.117.000422

McCarthy, K.S., M. Parker, A. Ameerally, S.L. Drake and M.A. Drake. 2017. Drivers of choice for fluid milk versus plant-based alternatives: what are consumer perceptions of fluid milk? Journal of Dairy Science 100(8): 6125-6138. https://doi.org/10.3168/jds.2016-12519

Meijaard, E., J. Abrams, D. Juffe-Bignoli, M. Voigtand D. Sheil. 2020. Coconut oil, conservation and the conscientious consumer. Current Biology 30(13): 757-758. https://doi.org/10.1016/j.cub.2020.05.059

Misselwitz, B., D. Pohl, H. Frühauf, M. Fried, S.R. Vavricka and M. Fox. 2013. Lactose malabsorption and intolerance: pathogenesis, diagnosis and treatment. United European Gastroenterology Journal 1(3): 151-159. https://doi.org/10.1177/2050640613484463

National Coffee Association (NCA). 2020. National coffee data trends report. NCA, New York, NY, USA. Available at: https://www.ncausa.org/Newsroom/NCA-releases-Atlas-of-American-Coffee

Nepstad, D., D. McGrath, C. Stickler, A. Alencar, A. Azevedo, B. Swette, B., T. Bezerra, M. DiGiano, J. Shimada. R.S. Da Motta, E. Armijo, L. Castello, P. Brando, M.C. Hansen, M. McGrathHorn. O. Carvalho and L. Hess. 2014. Slowing Amazon deforestation through public policy and interventions in beef and soy supply chains. Science 344(6188): 1118-1123. https://doi.org/10.1126/ science. 1248525

Nielsen Company. 2018. The rise and rise again of private label. Nielsen Company, Diemen, the Netherlands. Available at: https:/www.nielsen.com/wp-content/uploads/sites/3/2019/04/global-private-labelreport.pdf

Oatly. 2017. Sustainability report 2017. Oatly, Malmö, Sweden. Available at: https://www.oatly.com/uploads/ attachments/cjp9gpbd709c3mnqr8idyecwy-sustainability-report-2017-eng.pdf

Oatly. 2020. Sustainability report 2020. Oatley, Malmö, Sweden. Available at: https://www.oatly.com/uploads/ attachments/ckqqvrqz109kv9fgibgh258k8-oatly-sustainability-report-2021-web.pdf

Oltenacu, P.A. and D.M. Broom. 2010. The impact of genetic selection for increased milk yield on the welfare of dairy cows. Animal Welfare 19(1): 39-49.

People for the Ethical Treatment of Animals (PETA). 2019. Monkeys chained, abused for coconut milk. A PETA Asia Investigation. Available at: https://investigations.peta.org/monkeys-abused-coconut-milk/

Poore, J. and T. Nemecek. 2018. Reducing food's environmental impacts through producers and consumers. Science 360(6392): 987-992. https://doi.org/10.1126/science.aaq0216

Qin, L.Q., J.Y. Xu, P.Y. Wang, J. Tong and K. Hoshi. 2007. Milk consumption is a risk factor for prostate cancer in Western countries: evidence from cohort studies. Asia Pacific Journal of Clinical Nutrition 16(3): 467-476. 
Rojas-Downing, M.M., A.P. Nejadhashemi, T. Harrigan and S.A. Woznicki. 2017. Climate change and livestock: impacts, adaptation, and mitigation. Climate Risk Management 16: 145-163. https://doi. org/10.1016/j.crm.2017.02.001

Ruxton, C.H.S. and E. Derbyshire. 2008. A systematic review of the association between cardiovascular risk factors and regular consumption of oats. British Food Journal 110(11): 1119-1132. https://doi. org/10.1108/00070700810918027

Savage, J.H., A.J. Kaeding, E.C. Matsui, and R.A. Wood. 2010. The natural history of soy allergy. Journal of Allergy and Clinical Immunology 125(3): 683-686. https://doi.org/10.1016/j.jaci.2008.12.678

Schuppli, C.A., M.A.G. Von Keyserlingk and D.M. Weary. 2014. Access to pasture for dairy cows: responses from an online engagement. Journal of Animal Science 92(11): 5185-5192. https://doi.org/10.2527/ jas.2014-7725

Song, Y., J.E. Chavarro, Y. Cao, W. Qiu, L. Mucci, H.D. Sesso and J. Ma. 2013. Whole milk intake is associated with prostate cancer-specific mortality among US male physicians. The Journal of Nutrition 143(2): 189-196. https://doi.org/10.3945/jn.112.168484

Sprouts Farmers Market. 2021. Survey by sprouts looks into new year eating habits, reveals young Americans are likely to shift away from meat. Available at: https://about.sprouts.com/press-release/survey-bysprouts-looks-into-new-year-eating-habits-reveals-young-americans-are-likely-to-shift-away-frommeat/

Statista. 2021. Total coffee consumption volume in China from crop year 2014/15 to 2019/20 with a forecast for 2020/21 (in 1,000 bags). Statista Inc., New York, NY, USA. Available at: https://www.statista. com/statistics/1046674/china-coffee-consumption-volume/

Storhaug, C.L., S.K. Fosse and L.T. Fadnes. 2017. Country, regional, and global estimates for lactose malabsorption in adults: a systematic review and meta-analysis. The Lancet Gastroenterology \& Hepatology 2(10): 738-746. https://doi.org/10.1016/S2468-1253(17)30154-1

The Good Food Institute (GFI). 2020. Good food retail report. Benchmarking the top U.S. retailers on plantbased sales strategies. GFI, Washington, DC, USA.

United States Food and Drug Administration (USFDA). 2020. Code of Federal Regulations (CFR). Food and Drugs, Title 21, Vol. 2, 21CFR101.81. USFDA, Silver Spring, MD, USA. Available at: https:// www.accessdata.fda.gov/scripts/cdrh/cfdocs/cfcfr/cfrsearch.cfm?fr=101.81

United States Food and Drug Administration (USFDA). 2021. Electronic Code of Federal Regulations. Title 7: Agriculture, 205G. USFDA, Silver Spring, MD, USA. Available at: https://www.ecfr.gov/cgi-bin/ text-idx?tpl=/ecfrbrowse/Title07/7cfr205_main_02.tpl

Van Hulzen, K.J.E., R.C. Sprong, R. Van der Meer and J.A.M. Van Arendonk. 2009. Genetic and nongenetic variation in concentration of selenium, calcium, potassium, zinc, magnesium, and phosphorus in milk of Dutch Holstein-Friesian cows. Journal of Dairy Science 92(11): 5754-5759. https://doi. org/10.3168/jds.2009-2406

VeganBits. 2020. Vegan demographic 2020 - USA, and the world. Available at: https://veganbits.com/ vegan-demographics/

Ventura, B.A., M.A.G. Von Keyserlingk, C.A. Schuppli, C.A. and D.M. Weary. 2013. Views on contentious practices in dairy farming: the case of early cow-calf separation. Journal of Dairy Science 96(9): 6105-6116. https://doi.org/10.3168/jds.2012-6040

Weinberger, T. and S. Sicherer. 2018. Current perspectives on tree nut allergy: a review. Journal of Asthma and Allergy 11: 41. https://doi.org/10.2147/JAA.S141636

Westhoek, H., J.P. Lesschen, T. Rood, S. Wagner, A. De Marco, D. Murphy-Bokern, A. Leip, H. Van Grinsven, M.A. Sutton and O. Oenema. 2014. Food choices, health and environment: effects of cutting Europe's meat and dairy intake. Global Environmental Change 26: 196-205. https://doi. org/10.1016/j.gloenvcha.2014.02.004

Westhoek, H., T. Rood, M. Van den Berg, J. Janse, D. Nijdam, M. Reudink and E. Stehfest. 2011. The protein puzzle. PBL Netherlands Environmental Assessment Agency, The Hague, the Netherlands. Available at: https://www.pbl.nl/en/publications/meat-dairy-and-fish-options-for-changes-in-production-andconsumption 
Willett, W., J. Rockström, B. Loken, M. Springmann, T. Lang, S. Vermeulen, T. Garnett, D. Tilman. F. DeClerk, A. Wood, M. Jonell, M. Clark, L.J. Gordon, J. Fanzo, C. Hawkes, R. Zurayk, J.A. Rivera, W. De Vries, L.M. Sibanda, A. Afshin, A. Chaudhary, M. Herrero, R. Agustina, F. Branca, A. Lartey, S. Fan, B. Crona, E. Fox, V. Bignet, M. Troell, T. Lindahl, S. Singh, S. Cornell, S. Reddy, S. Narain, S. Nishtar and C.J.L. Murray. 2019. Food in the anthropocene: the EAT-Lancet Commission on healthy diets from sustainable food systems. The Lancet 393(10170): 447-492. https://doi.org/10.1016/ S0140-6736(18)31788-4 
